\title{
The Cause and Impact of Child Labor on a Child's Short and Long-Term Health
}

\author{
Ms. Shemily. P. John, Dr. K.R. Murugan
}

\begin{abstract}
The International Labor Organization (ILO) defines the worst forms of child labor as hazardous work, this includes work involving handling arms conflict, prostitution, pornography and more. It is no surprise that the nature of such work pose physical and mental health risk to the child. The aim of this paper is to define child labor, its causes and the health risk they pose both directly and indirectly, immediately and in the long-term. Children exposed to those health risk suffer with illness in the future as well as employability values. Moreover, we discuss the routes and actions large entities have taken to combat child labor such as enforcing conventions, work procedures and providing support to the children and their finales. We will require a louder voice to further aid in increasing the reach on this matter to effectively eradicate childlabor.
\end{abstract}

Index Terms - Child, health, mental, physical, wellbeing.

\section{INTRODUCTION}

It has been decades that child labor has been one of the major global concerns associated with unfair education opportunities, poverty and gender inequality. The International Labor Organization (ILO) estimates that there are 151 million children engaged in work in developing countries. This is an alarming statistic. What is more concerning are that out of the estimated 151 million child laborers, about 72 million children are involved in hazardous work, these include handling arms conflict, prostitution, pornography and more. This entails greater health risk for the child.

The purpose of this research is to define child labor, observe the current state of child labor, identify the cause and ways child labor could be a health risk and then prove that it could have long-term effects on the child.

Any study related to child labor must first begin with a definition of what the researcher means by child labor. The following section identifies definition posed by the ILO and United Nations International Children's Emergency Fund (UNICEF). Furthermore, section 3 discusses the causes of child labor. Deciding factors that lead to child labor is not easy, there are simply many. This section covers the one of the common reasons from a child'sperspective.

In addition to stating causes, it is important to have a clear view on the current state of child labor. In section 4 we observe the child labor in numbers based on region, age and type of work. Moreover, we try to focus on the alarming numbers of children involved in hazardous work and we later

Ms. Shemily. P. John. Co-Ordinator of General Studies Unit University College of Bahrain

Dr. K.R. Murugan, PhD Guide , Professor and Dean Faculty of Arts Department of Social Work, Alagappa University, Karaikudi discuss how their health is at risk in section 5. Section 5 also explores studies from various regions of children who suffer some form of health risk. We then transition to see how these health risks affect the child long-term in Section6.

Finally, with all the health risk stated, what has been done to combat child labor? Section 6 discusses the ways big entities have participated in placing measures, procedures and conventions to stop child labor, especially the way they have supported the children and their families. We then conclude with our findings and a recommendation to what additional measures we must take to effectively eradicate child labor in today'sworld.

\section{WHAT IS CHILDLABOR?}

Any research conducted in child labor must define the term "child labor" itself. Many researchers and literature writers avoid labelling any one activity as child labor, it was simply not easy to do so. Countries such as Pakistan consider it as wage work, while Vietnam label child labor as market work that is harmful to the future wellbeing of the children. However, there is a precedent posed by the International Labor Organization's (ILO) article C138 which later turned into a standard that is now signed by 135 countries (1). C138 intends to abolish "child labor" and to increase minimum age of emolument to a "a level consistent with the fullest physical and mental development of young persons" (International Labour Organization, "C138 - Minimum Age Convention, 1973 "). This states that it is the age appropriateness of certain activities depend on the effects that activity has on the health and development of the child. This means that any activity that is mentally, physically, socially or morally harmful to children; or disrupts schooling(5).

The ILO's Statistical and Monitoring Program on Child Labor (SIMPOC) is an international entity that tracks child labor around the world. At the time of this writing, a child who is under 12 and is working 1 or more hours per day, is considered as a child laborer. A child who is under 14 and works at least 14 hours per week or 1 or more hours per week is involved in a "hazardous by nature or circumstance", and a child who is under 17 that works in an "unconditional worst form of child labor" such as armed conflict and prostitution (2).

The United Nations International Children's Emergency Fund (UNICEF) also has a definition to child labor which primarily also considers the number of appropriate hours. UNICEF describes child labor as work that exceeds the 
minimum number of hours, based on the activity and child's age which may be harmful (3). This has been further specified assuch,

- Ages 5-11: At least one hour of economic work or 28 hours of domestic work perweek.

- Ages 12-14: At least 14 hours of economic work or 28 hours of domestic work perweek.

- Ages 15-17: At least 43 hours of economic or domestic work perweek.

\section{CAUSES BEHIND CHILDLABOR}

The causes behind child labor are a complex one and of many reasons. This research paper primarily covers the reasons mentioned in Jennie Johansson's published research from Sodertons University, which itself if based on a book called "What Works for Working Children" by Boyden J, Ling B, Myers W. The book highlights the subject of child labor using published and unpublished literature. The book provides insights on the childls perspective and what they consider a priority based on the circumstances they are in. This does not cover the plethora of other plausible reasons, but the theory raised here is sufficient for this research.

\section{a. Contribution to thefamily}

While some children are told or forced to work by their families, children in developing countries do actively want to support their families. Families tend to need all the help they could get when it comes to contributing to the family in come or Haley with unpaid household work. Johansson findings also state that children find it very plausible to help their family especially when their survival depends on it(3).

\section{b. Self-actualization}

This theory indicates that some children would work even if they did not have to. There is a feeling of independence and maturity experienced by children (4). Many children would like to work because they feel they could learn and that it is a means for them to gain education and that it will aid in developing in the direction of their own ambition.

\section{c. Shift infamily-dynamics}

This theory may reflect to the irresponsibility of the parents. As it turns out based on Johansson findings along side with The World Bank, the larger the house hold the increased negligence of the parents as they fail to invest completely in every child's schooling and development. As a result, this leads to higher rates of "malnutrition, child mortality and morbidity" (Johansson 10). This goes hand in hand that larger families in developing countries often have increased participation in child labor.

Families with women as single heads of the family are the commonly the poorest as they have to work outside the house hold leaving the children alone or with elders Boys with Single mothers are very likely to partake in laboring to contribute to the family. Gender inequality within such communities involve the males working more, making up $58 \%$ of the estimated child labor market (5).

Other shifts such as debts, job loss and failing harvests can threaten the livelihood causing condition common for children to enter into child labor.

\section{d. Poverty}

The most common theory behind the cause of underage work. ILO states that $20 \%$ of the household income are from chidlabour. However to say that poverty is the only reason for child labour would be incorrect. If poverty was the sole reason then the same pattern can be seen in other countries which is not the case. In fact, children from wealthier family are more likely to get involved in child labor (3). The difference is that wealthier families have more opportunities, such as the a ability to finance transportation to and fro the job-site.

Poverty also increased the demand for child laborers. Employers who are not doing well economically usually turn ti Chile labour to keep their cost to a minimum. Poor children, being with less education, fewer employment options and are less aware of their right means cheaper employment.

\section{THE STATE OF CHILD LABOR TODAY AND INVOLVEMENT IN HAZARDOUSLABOR}

The International Labour Organization (ILO) produced a statistical publication as part of aligning with the Sustainable Development Goals (SDG). In this section, it is best to first derive a clear estimate on the number of children who are currently working in child labour and in hazardous work as described in section 2. ILO states that there are estimated 218 million children in employment, out of which 151 million are in child labor, with 72 million of them in hazardous work (5). 


\section{Children in \\ hazardous \\ work, \\ $72,525,000$}

\section{Children in}

child labour,

$151,622,000$

Children in

employment,

$218,019,000$

Figure 4.0: 2016 Global Estimates of children in hazardous work, in child labour, and in employment Child labour is widespread in developing countries, especially in the African followed by the Americas (5).

REGIONAL PREVALENCE OF CHIID LABOUR
$\begin{array}{ll}\text { - Africa } & 19.6 \% \\ \text { | Americas } & 5.3 \% \\ \text { | Arab States } & 2.9 \% \\ \text { - Asia and the Pacific } & 7.4 \% \\ \text { - Europe and Central Asia } & 4.1 \%\end{array}$

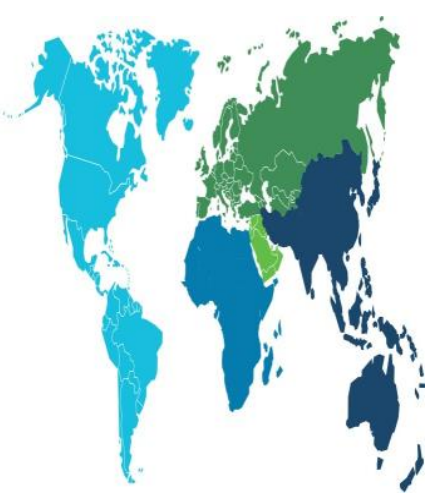

Figure 4.1: Regional prevalence of child labour

To further support claim in section 3.3 where males make up most of the child labour market, ILO has also stated that about 88 million males, or $58 \%$ of the child labor market is made up of males. Majority of the child labor market is made up of children ages 5 to 11 . Most of them are involved with agriculture followed bu Industry work such as in factories. 
AGE PROFILE

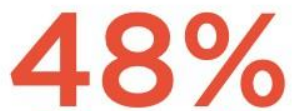

5-11 years-olds

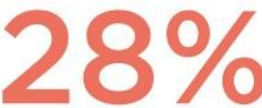

12-14 years-olds

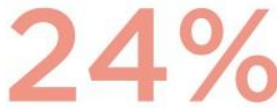

15-17 years-olds
GENDER

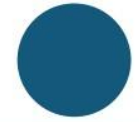

$58 \%$

88 million

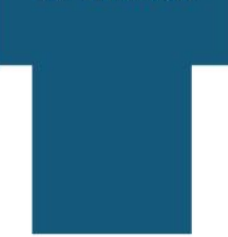

ECONOMIC ACTIVITY

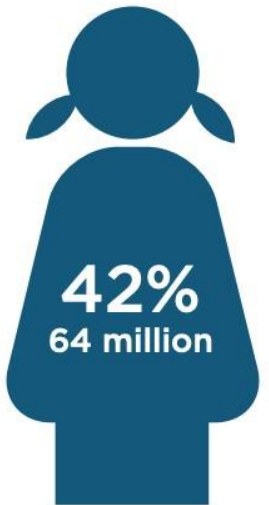

$70.9 \%$

Agriculture

$11.9 \%$

Industry

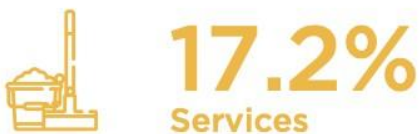

Figure 4.2: Children estimate I child labour by age, gender, and activity

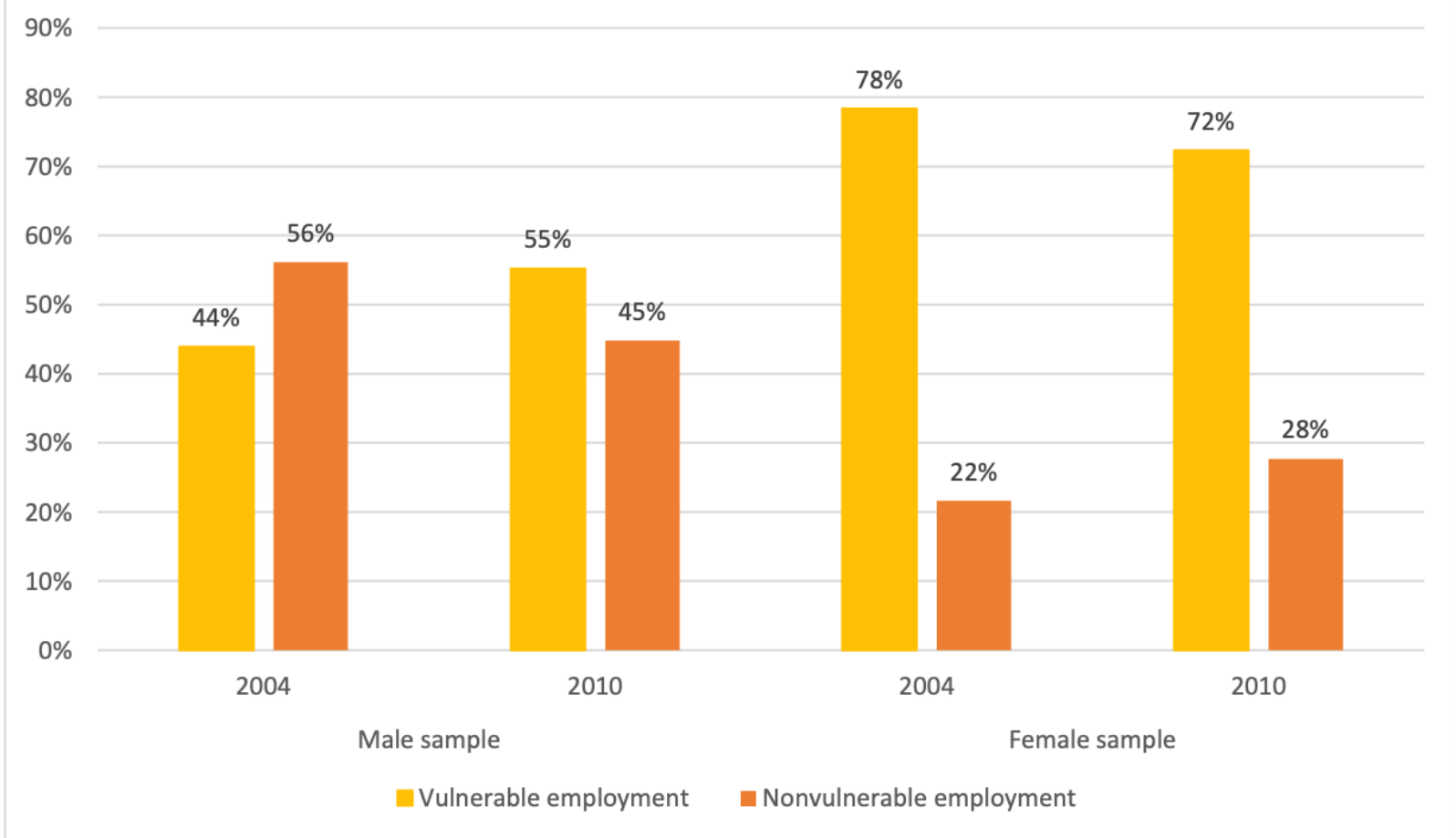

Figure 6.0: Vulnerable employment by year and gender

The main focus point of this research is on how child labor troubling. It is these children that require special attention and affects the health of their wellbeing. A substantial number of it is the ILO's main goal to eradicate. The below table shows children working in "hazardous" activity as defined by ILO as the current numbers of children working in hazardous being "directly endangers their health, safety, and moral circumstances byregion. development" (International Labour Office (ILO) 5) is quite

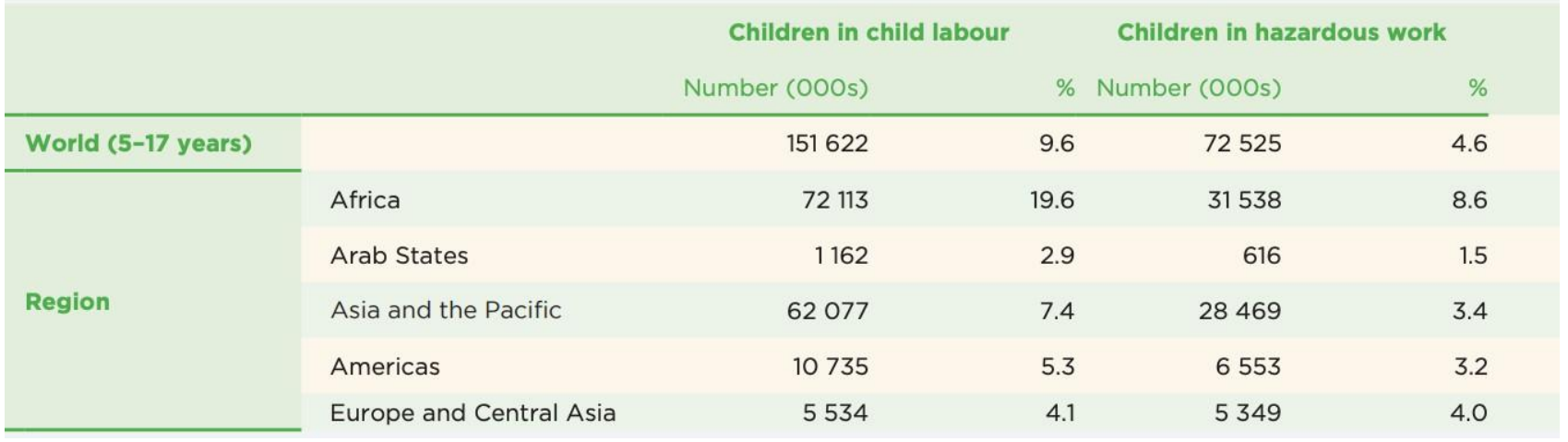


Table 4.0: Number and percentage of children in child labour and hazardous work, by region, 2016

Additionally, the below table shows the cohorts of children involved in hazardous work by age group. It is quite concerning that 19 million children of the age group 5 to 11 years old are being part of hazardous activities, endangering their health, safety and moraldevelopment.

\begin{tabular}{llrrrr} 
& & Children in child labour & \multicolumn{3}{c}{ Children in hazardous work } \\
& & Number (OOOs) & \% & Number (00Os) & \% \\
\hline \multirow{2}{*}{ Age range } & $5-11$ years & 72585 & 8.3 & 19020 & 2.2 \\
& $12-14$ years & 41887 & 11.7 & 16355 & 4.6 \\
& $15-17$ years & 37149 & 10.5 & 37149 & 10.5 \\
& $5-17$ years & 151622 & 9.6 & 72525 & 4.6 \\
\hline
\end{tabular}

Table 4.1: Number and percentage of children in child labour and hazardous work, by age group, 2016

\section{HEALTH ISSUES THE CHILDREN ARE POSEDTO}

A published journal article by Ibrahim A and Abdalla M, summarizes 25 articles from various regions, concerning the effects of specific hazardous work on a child's health (6). It highlights the physical, mental and social health deterioration in details. This section further summarizes their finding and have been categorized to 4 types of common health complications due to child labor.

\section{a. Affected physicalgrowth}

One of the primary cause of physical growth damage is due to malnutrition. A study in Pakistan reported that child labor is associated with wasting, stunning and chronic malnutrition (7). A study in India compared physical growth and genital development between working and non-working children. The study observed that working children had lower Body Mass Index (BMI), a shorter build and delayed gent; development, though no major differences were seen among females (8).

\section{b. Injuries}

A study in Bangladesh showed that younger children are more likely to suffer injuries such as backaches, exhaustions and burns than older children. The likely occurrences of these injuries and illness increase the number if hours of work increases (9). In addition, a study in Iran showed that the most common injury is falling from heights, about $44 \%$, with cuts being the most common injuries. These children were also not provided and preventive device (10). Another study in Nicaragua stated the most common form of child labor, agriculture, exposes children to pesticide poisoning (11).

\section{c. Diseases}

Working in hazardous activities not only exposes children to injuries but also to infectious diseases. A study in Iran dived in to the prevalence of viral infections such as HIV in working children. In fact, the number was higher in working children than in general public. $4.5 \%$ of children with HIV positive, $1.7 \%$ were hepatitis $\mathrm{B}$ positive and $2.6 \%$ were hepatitis C positive (12). It is seen the high is risk is due to work involve in prostitution, or having parents who used drugs or are infected with HIV.

\section{d. Psychology}

All studies involved in journaled article brought forward case of mental and behavioral disorders.A study in Bangladesh stated the prevalence in child abuse and exploitation. Physical abuse was higher in children (13). Similarly in Turkey, it is seen that $62.5 \%$ of the child laborers were experiencing some form of abuse, with $21.8 \%$ being physical abuse, $53.5 \%$ being emotional, and $25.2 \%$ sexual. $100 \%$ were subjected to physical neglect while $28.7 \%$ to emotional neglect(14).

Sexual assault is indeed the highest number when it comes to a study in Nigeria, at $77.7 \%$ experiencing sexual assault. Most of these were from customers and experienced by girls who were younger than 12 years old and had no formal education (15).

\section{EFFECTS OF CHILD LABORERS INADULTHOOD}

The above section discusses the ways children's health is at risk. This section specifically outlines how the above risks carry on into adulthood as the child grows, the problems the child may face in the long-run. This can be split in to direct and indirect implications.

\section{a. Directimplications}

1. Exposure to pesticides, chemicals, dust and carcinogens used in agriculture, mining or factories increase the risk of cancer.

2. In India, it is found that large number of children who were working in industries later tend to have higher rates of TB and silicosis(16).

3. Heavy lifting and bad posture increased musculoskeletal problems developing in later life(16).

\section{b. Indirectimplications}

The indirect implication, though not so many, are a very common outcome of child labor but with grave impact. These include:

1. Spending time working means less time invested in education. This affectedemployability.

2. Emotional distress caused can reflect on the characteristic and personality of the child as they grow.

A study in Tanzania involved samples of showed that a sample of children who have worked more number of hours is directly proportional to the value of their employability as they faced difficulties in securing and maintaining a job (17). The below chart shows that the number of "vulnerable 
employment" has increased.

\section{ACTIONS TAKEN TO COMBAT CHILDLABOR}

Great movements have been taken to place to raise awareness and to combat child labor. The following sections outlines the facilities and actions taken by well known entities to help eradicate child labor

\section{a. Bureau of International Labor Affairs(ILAB)}

One example is the Bureau of International Labor Affairs (ILAB). ILAB contributed in reducing the rates of hazardous labor in half since the year 2000. Since 1995 ILAB helped reduce the number of child laborers by 94 million. They also engage with companies to raise awareness and that children are not involved in global supply chains (18)

b. United Nations International Children's Emergency Fund(UNICEF)

UNICEF helps provide access to basic services, enforcing child protection systems and promoting the social change. They have been in close ties with government and releasing programs against child labor.

Additionally, UNICEF have helped over 9,000 children who were working in worst forms or hazardous activities and who were separated from their families. They were provided shelter, food and health care, as well as reuniting them with theirfamilies.

They have also offered psycho-social counseling and legal help. They were provided financial assistance to get to school and enter vocational training(19).

\section{c. International Labour Organization(ILO)}

The ILO dives in deep in to the process working with government entities and law makers. They have set in standards for companies to follow and rules to adhere. They have defined the nature of work that is not allowed for specific ages, and this is done by imposing conventions that have countries sign. An example of this is the Convention No. 138 , which was also mentioned to set a specific hours for specific age groups and activities (20).

They have also introduced procedures in to a workplaces such as Social auditing that request company to undertake and evaluate the working conditions. They have also enforced in applying safety and health management systems to generally help prevent accidents.

They have provided support to children found in child labour and have provided education. They are striving on eliminating the need for child labor, ensuring that children are not involved in the economic's supply chain(20).

\section{CONCLUSION ANDRECOMMENDATIONS}

We have clarified how we are to define child labour given that we cannot label any one activity as child labor. The
International Labour Organization (ILO) and United Nations International Children's Emergency Fund (UNICEF) have provided a very clear definition for child labor which is defined by the nature of the work and the work hours implied by agegroup.

Furthermore, we have dwelled in to the causes of child labor. It was concluded that poverty is not the sole determinant for child labor. It is in fact the shift of the family dynamics and the need be a part of the family and to contribute to it. Self-actualization is also good driving factor to child labor, where the sense of responsibly and maturity encourages a child towork.

It is seen that child labor is still a major concern with data provided by ILO. What is more concerning is that 19 million of children are still a part of hazardous work, which includes armed conflicts, pornography, prostitution and more. It is also observed that the African region is where most of the children were involved in hazardous work.

This research confirms that the involvement in hazardous work means higher risk to the child's health. We have see the ways child labor can affect the health of the child physically and mentally, both directly and indirectly in the long-run. In addition to the physical injuries and assault, children are exposed to sexual assault and mental abuse causing sociological difficulties. We ave also observed that the lack of time invested in education has caused vulnerable employments due to affected employability value Carcinogens, pesticides, exposure to disease have also affected Childs growth, development and garnered higher chances of falling ill in the future.

Given that big entities such as ILO, UNICEF and that Bureau of International Labor Affairs (ILAB) have taken massive initiatives to combat child labor, my main recommendation is to have increased education and awareness on the matter They may have placed strict procedures, signatory conventions and provided support, though through the research I can tell perhaps more awareness on the matter will be required. We must encourage introducing sociological projects concerning child labor to educational facilities such as schools or universities to shed light in the matter. There needs to be a louder voice to garner the attention of potential enablers. We need to get the stories of those who are affected out, as the youngest Nobel Prize laureate, Malala Yousafazi, puts it, "We realize the important of our voice when we aresilenced."

\section{REFERENCES}

[1] International Labour Organization. "C138 - Minimum Age Convention, 1973 (No. 138).” International Labour Organization, 19 June 1976, www.ilo.org/dyn/normlex/en/f? p=normlexpub:12100:0::no::P12100_ilo_code:C138.

[2] International Labour Organization. "The Worst Forms of Child Labour." International Labour Organization, 2006, www.ilo.org/ipec/Campaignandadvocacy/Youthinaction/C182-Yout h- orientated/worstforms/lang--en/index.htm. 
[3] Johansson, Jennie. "ACase Study in BabatiTown, Tanzania." Causes of Child Labour, 2009, p. www.diva-portal.org/smash/get/diva2:358647/FULLTEXT01.pdf.

[4] Boyden, Jo. What Works for WorkingChildren. RäddaBarnen, Florence, Innocenti Publications, 1998.

[5] International Labour Office (ILO). Global Estimates of Child Labour: Results and Trends, 2012-2016. Geneva, ILO publications, 2017.

[6] Ibrahim, M Abdalla, Abdalla, Salma. "Child Labor and Health: A Systematic Literature Review of the Impacts of Child Labor on Child's Health in Low- and Middle-Income Countries." Journal of Public Health, vol. 41, no. 1, 20019, pp. 18-26, academic.oup.com/ jpubhealth/article/41/1/18/4835667.

[7] Ali M, Shahab S, Ushijima $\mathrm{H}$ et al. Street children in Pakistan: a situational analysis of social conditions and nutritional status. Soc Sci Med2004;59(8):1707-17.

[8] Ambadekar NN, Wahab SN, Zodpey SP et al. Effect of child labour on growth of children. Public Health1999;113(6):303-6.

[9]9. Ahmed S, Ray R. Health consequencesof child labourin Bangladesh. DemogrRes2014;30:111-50.

[10] Hosseinpour M, Mohammadzadeh M, Atoofi M. Work-related injuries with child labor in Iran. Eur J PediatrSurg2014;24(01):117-20

[11] Corriols M, Aragón A. Child labor and acute pesticide poisoning in Nicaragua: failure to comply with children's rights. Int J Occup Environ Health2010;16(2):175-82.

[12] Foroughi M, Moayedi-Nia S, Shoghli A et al. Prevalence of HIV, HBV and HCV among street and labour children in Tehran, Iran. Sex TransmInfect2016;93(6):421-23.

[13] Hadi A. Child abuse among working children in rural Bangladesh: prevalence and determinants. Public Health2000;114(5):380-4.

[14] Öncü E, Kurt AÖ, Esenay FI et al. Abuse of working children and influencing factors, Turkey. Child Abuse Neg12013;37(5):283-91.

[15] Audu B, Geidam A, Jarma H. Child labor and sexual assault among girls in Maiduguri, Nigeria. Int J GynecolObstet2009 Jan31;104(1):64-7.

[16] Fassa, Anaclaudia. "Health Benefits of Eliminating Child Labour." Costs and Benefits of the Elimination of Child Labour, vol. 1, no. 1, 1997, pp.23-31.

[17] Burrone, Giannelli, Sara, Gianna. "Does Child Labor Lead to Vulnerable Employment in Adulthood? Evidence for Tanzania." DISCUSSION PAPER SERIES, vol. 1, no. 1, 2019, pp. 20-21,poseidon01.ssrn.com.

[18] Taylor, Katie. "WHAT IS CHILD LABOR AND WHAT IS BEING DONE TO STOP IT?” World Vision Advocacy, 30 May 2019, worldvisionadvocacy.org/2019/05/30/what-is-childlabor-and-what-is-being-done-to-stop-it

[19] UNICEF. "To Eliminate Child Labour, Attack It at Its Roots, UNICEF Says." UNICEF, 8 Oct. 20 13, www.unicef.org/media/ media_70610.html\#: :text=UNICEF's\%20approach\%20to\%20preven ting $\% \overline{2}$ and,out $\% 20$ pro grammes $\% 20$ against $\% 20$ child $\% 20$ labour.

[20] "Eliminating and Preventing Child Labour." International Labour Organization,

www.ilo.org/wcmsp5/groups/public/---dgreports/---dcomm/---publ/do cuments/publication/wcms_456960.pdf. 